\title{
Methylmercury and long-chain n-3 fatty acids of 88 fish species commonly consumed in Hong Kong
}

\author{
Stephen Wai Cheung Chung ${ }^{1 *}$, Siu Kuen Tong ${ }^{1}$, Ying Xiao ${ }^{2}$ and Yuk Yin $\mathrm{Ho}^{3}$
}

\begin{abstract}
Background: Fish is considered by nutritionists as the main source of omega 3 (n-3) polyunsaturated fatty acids which is not available in common edible plant oils. However, methylmercury (MeHg) in fish is considered as the major contributor from food. Risk benefit analysis of $\mathrm{MeHg}$ and n-3 fatty acids became a hot topic in the past decade. Different risks and benefit analysis on the consumption of fish have been reported, but most of the analyses were based on the data extracted from different databases.

Results: This study provided the levels of n-3 fatty acids, $\mathrm{MeHg}$, and total mercury (tHg) of different fish species commonly consumed in Hong Kong. Among the sampled 88 species of fresh/frozen whole fish, all samples were found to contain quantifiable amount of $\mathrm{n}-3$ fatty acids, $\mathrm{MeHg}$, and tHg. The levels of $\mathrm{n}-3$ fatty acids (EPA plus DHA) in local or imported fish species are ranging from 0.31 to $20.6 \mathrm{mg}$ per $\mathrm{g}$ while the highest level was found in Atlantic salmon. For MeHg, the highest content was found for alfonsino at the level of $0.827 \mu \mathrm{g}$ per $\mathrm{g}$.

Methods: A modified AOAC 990.08 was single laboratory validated and used for analysis n-3 fatty acids content of fish samples.

Conclusions: This paper presents the n-3 fatty acids and MeHg content in 88 fish species. These original results are consistent with overseas findings and are useful in risk/benefit assessment of fish consumption recommendations in general.
\end{abstract}

Keywords: Fish species; n-3 fatty acids; Methylmercury; Total mercury; EPA; DHA; Hong Kong

\section{Background}

For many years, fish has often been the focus of attention in both contaminants and nutritional studies. Nutritionists [1] consider seafood to be an important source of highquality proteins, vitamin $\mathrm{D}$, and essential fatty acids (EFAs). EFAs are similar to vitamins in terms of their importance to our health. Unlike vitamins, EFAs are macronutrients (i.e., necessary in g/day). A joint study released by the Food and Agriculture Organization and the World Health Organization [2] recommends that at least $6 \%$ to $10 \%$ of our daily calorie intake be in the form of EFAs.

Current dietary guidelines recommend a diet low in saturated fatty acids (SFAs), with a moderate amount of

\footnotetext{
* Correspondence: swcchung@fehd.gov.hk

${ }^{1}$ Food Research Laboratory, Food and Environmental Hygiene Department, 4/F Public Health Laboratory Centre, 382 Nam Cheong Street, Shek Kip Mei, Hong Kong, China

Full list of author information is available at the end of the article
}

monounsaturated fatty acids (MUFAs) and polyunsaturated fatty acids (PUFAs), including the n-6 and n-3 families. The recommended ratio of n-6 to $n-3$ usually varies between 4:1 (or less) and 10:1. The human body cannot produce all n-3 fatty acids, but two of them, it needs. These two, linoleic acid and alpha-linolenic acid, are widely distributed in plant oils. Fish oils contain the longer-chain n-3 fatty acids, eicosapentaenoic acid (EPA) and docosahexaenoic acid (DHA), while other marine oils, such as from seal, contain significant amounts of docosapentaenoic acid (DPA). The n-3 fatty acids found in fish oils and marine oils can help to fulfill the requirement of EFAs.

The level of $\mathrm{MeHg}$ in fish is of particular concern worldwide because significant exposure to $\mathrm{MeHg}$ can cause adverse effect to the nervous system, especially the developing brain. In 2000, JECFA established a PTWI of $3.3 \mathrm{ug}$ per $\mathrm{kg}$ bw per week for the general population 
but highlighted that the fetus and infant might be at a greater risk of toxic effects [3]. In 2003, this PTWI was reduced to $1.6 \mathrm{ug}$ per $\mathrm{kg}$ bw per week following further risk assessment [4]. This value was considered to be sufficient to protect the developing fetus, which are the most sensitive to $\mathrm{MeHg}$.

However, the health risk of chemicals/nutrients in fish is usually assessed separately. In recent years, the evolving science and debate concerning the risks and benefits of consuming fish have resulted in confusion as to how much fish should be consumed. National food safety agencies have recognized the need to provide useful, clear, and relevant information to populations that are concerned about making the healthiest choices when considering whether or not to eat fish $[5,6]$.

Mahaffey [7] noted the interplay between fatty acids and $\mathrm{MeHg}$ and provided data on typical contents by species of fish or shellfish. Besides, she also commented that the choice of fish species by consumers is crucial to the balance between the risks and benefits of consuming fish. AFSSA [8] concluded the advantages of diversifying the consumed fish and seafood species in terms of proportions and provisioning origins in order to ensure a rational balance between benefits and risks compatible with nutritional and toxicological recommendations. Mozaffarian et al. [9] reported the benefits of fish intake exceed the potential risks based on both the strength of the evidence and the potential magnitudes of effect. For women of childbearing age, benefits of modest fish intake, excepting a few selected species, also outweigh risks. Zhang et al. [10] concluded that the changes in fish consumption related to $\mathrm{MeHg}$ advisories have a minor influence on the intake of EPA and DHA and on the percentage of women with EPA and DHA intake exceeding the guideline for Japanese women. Subsequently, US FDA [11] published a draft quantitative risk and benefit assessment report on the consumption of commercial fish and focused on fetal neurodevelopmental effects. Nevertheless, this simulation could aid the selection of fish species in order to ensure adequate intake of EPA and DHA while minimizing exposure to $\mathrm{MeHg}$.

The 38th Session of the Codex Committee on Food Additives and Contaminants requested the Codex Alimentarius Commission to convene a Joint Food and Agriculture Organization of the United Nations (FAO)/ World Health Organization (WHO) Expert Consultation on the health risks associated with the presence of $\mathrm{MeHg}$ and dioxins in fish as well as the health benefits of fish consumption. FAO and WHO then convened a Joint Expert Consultation in Rome in January 2010 to assess the issues. The Expert Consultation concluded that fish is a major source of food and essential nutrients in some populations, and consumption of fish provides energy, protein, and a range of other important nutrients, including the long-chain n-3 polyunsaturated fatty acids [12]. Among the general adult population, the consumption of fish, particularly fatty fish, lowers the risk of mortality from coronary heart disease. There is an absence of probable or convincing evidence of risk of coronary heart disease associated with $\mathrm{MeHg}$.

Most of the levels of $\mathrm{MeHg}$ (or tHg) and n-3 fatty acids used for the discussion were based on data extracted from different databases. However, levels of $\mathrm{MeHg}$ contamination vary widely. Among different species of tuna, there is a three-fold difference in mean levels of contamination between canned light tuna $(0.128 \mathrm{ppm})$ and canned albacore tuna $(0.350 \mathrm{ppm})$ or tuna that is sold fresh or frozen (0.391 ppm) [13]. MeHg contamination also varies greatly between individual fish and depends on its species, age (size), mercury levels in living environment, and food sources. Therefore, the evaluation between $\mathrm{MeHg}$ and omega-3 fatty acids based on data extracted from databases might not truly reflected the correlation but provided a general picture of the relationship.

Among the literatures, the reports that analyzed both the levels of $\mathrm{MeHg}$ and omega-3 fatty acids in different fish species are rare. The CALIPSO study conducted by AFSSA has analyzed both the levels of MeHg and n-3 fatty acids of 30 different fish but not down to fish species.

Hong Kong is a city well known for its high consumption of seafood. Recently, around 90 commonly consumed fish species have been collected and analyzed for their total and $\mathrm{MeHg}$ contents. The exposure of tHg and $\mathrm{MeHg}$ from food in Hong Kong has also been assessed [14]. Besides, the fatty acid profiles of these fishes were analyzed. As FAO/WHO [12] encouraged member countries to generate representative data on levels of n-3 fatty acids, mercury, and dioxins in fish species in the form consumed in their countries, this paper summarized and presented the findings of $\mathrm{tHg}, \mathrm{MeHg}$, and $\mathrm{n}-3$ fatty acids (EPA and DHA) of these fish species.

\section{Methods \\ Samples}

Fish species commonly consumed in Hong Kong were randomly sampled during the sampling period of April to August of 2007 from various premises, including supermarkets and fresh provision shops, at different locations for marine fish or freshwater fish in whole fish form for identification:

- Local fish from wet markets and other fish-selling premises

- Imported fish for preparation by restaurant

Fish samples from the same batch were collected and sent to the Agriculture, Fisheries and Conservation 
Department (AFCD) for species identification. The samples were gutted and separated into edible portion including skin and flesh, homogenized and stored at $-20^{\circ} \mathrm{C}$ until they were analyzed. For each fish species, equal weight of the primary samples was mixed, ground, and remixed to obtain a single homogeneous composite sample before analysis. The composite fish samples were analyzed on composite basis for fatty acids (50 fatty acids in all). The number of fish species and the number of individual samples collected for each species were limited by resources available and availability of fish during the sampling period. Ideally, examination of more samples for each species would better reflect the mercury levels for each species.

\section{Analytical determination of $\mathrm{tHg}, \mathrm{MeHg}$, and fatty acids} For tHg determination, all food samples were digested according to modified AOAC Official Method 990.08. In brief, the samples were digested by concentrated nitric acid at $95^{\circ} \mathrm{C}$ for $2 \mathrm{~h}$. Then, $\mathrm{H}_{2} \mathrm{O}_{2}$ was added, and the mixture was kept at $95^{\circ} \mathrm{C}$ for another $1 \mathrm{~h}$. After dilution, the quantification of tHg was performed by a flow injection mercury analyzer equipped with an amalgam preconcentration system (FIMS 100, Perkin-Elmer, Wellesley, MA, USA).

For $\mathrm{MeHg}$, homogenized fish sample was extracted with $50 \% \mathrm{HCl}$ by sonication for $3 \mathrm{~h}$. After centrifugation, the extract was derivatized with sodium tetraphenylborate. The quantification of MeHg was performed by a gas chromatograph-mass selective detector, operating in the selective ion monitoring mode [15].

All fish samples were analyzed according to a slightly modified AOAC Official Method 996.06. In brief, the lipid of the samples was hydrolyzed by concentrated nitric acid. Pyrogallic acid was added to prevent oxidative degradation of fatty acids during acid hydrolysis while triundecanoin was added as internal standard. After hydrolysis, fatty acids extracted into diethyl ether were concentrated and then methylated to fatty acid methyl esters (FAMEs) with boron trifluroide as derivatizing agent. FAMEs yielded were quantitatively measured by using a gas chromatograph equipped with flame ionization detection system (6890: Agilent Technologies, Santa Clara, CA, USA). The separation was achieved with a SP$2560(100 \mathrm{~m} \times 0.25 \mathrm{~mm} \times 0.28 \mu \mathrm{m})$ column. The oven was hold at $100^{\circ} \mathrm{C}$ for $4 \mathrm{~min}$, then ramped to $240^{\circ} \mathrm{C}$ with rate of $3^{\circ} \mathrm{C} / \mathrm{min}$ and held for another $20 \mathrm{~min}$. The injector temperature was $225^{\circ} \mathrm{C}$ with split ratio of $150: 1$.

\section{Results and discussion Method}

Though a number of capillary columns claimed that they are suitable for the separation of FAMEs, none of them could baseline separate each FAMEs. In order to obtain better separation or more theoretical plates, the carrier gas was changed to hydrogen instead of helium. Upon such minor modification of the method, almost every peak of FAMEs standard could be well resolved except the peaks of $C 18: 1 n-7 t,-9 t$, and $-12 t$ that cannot be completely resolved. Further, the separation between the GC peaks of C22:1n-9 $t$ and C20:3n-3 became baseline separated (see Figure 1). In general, the limit of quantification can attain down to $0.004 \mathrm{mg}$ per $100 \mathrm{~g}$ flesh weight.

\section{$\mathrm{tHg}, \mathrm{MeHg}$, and fatty acid profile}

Table 1 summarized the fish species, tHg, MeHg level, and concentration $n-3$ fatty acids (EPA and DHA) of commonly consumed fish in Hong Kong. Levels of other n-3 fatty acids were summarized in Table S1. The fishes containing the highest amount of fat are Japanese eel, Altanic salmon, and yellow croaker, with levels of more than 10 per $100 \mathrm{~g}$, while those with the lowest content of fat are tonguefish and orange-striped emperor, with levels less than $300 \mathrm{mg}$ per $100 \mathrm{~g}$.

All of the samples were found to contain quantifiable amount of MUFAs and PUFAs. The levels of MUFAs and PUFAs in different fish species ranged from 27.2 to 9,730 to 67.9 to $4,140 \mathrm{mg}$ per $100 \mathrm{~g}$, respectively, while the highest MUFAs and PUFAs levels were found in Japanese eel and Atlantic salmon, respectively. Small amount of trans fatty acids was detected in most of the tested fish species except starspotted grouper, honeycomb grouper, Bombay duck, and white-edged lyretail while the highest level was found for grey mullet at $93.9 \mathrm{mg}$ per $100 \mathrm{~g}$.

For n-3 and n-6 PUFAs, the highest content was found for Atlantic salmon and grey mullet at the level of 2,900 and 1,980 mg per $100 \mathrm{~g}$, respectively. Regarding EPA, DHA, and DPA, fatty acids that need to be intake from food, the total amount varied from 31.3 to $2,510 \mathrm{mg}$ per $100 \mathrm{~g}$. No matter whether the individual or sum of these $\mathrm{n}-3$ fatty acids is concerned, the highest amount was found in Atlantic salmon. While Japanese eel, laced moray, grunt, yellow croaker, silver pomfret, false halibut, white trevally, purple amberjack, and yellowtail kingfish from region $\mathrm{B}$ were also found to contain more than $1,000 \mathrm{mg}$ per $100 \mathrm{~g}$ of these $\mathrm{n}-3$ fatty acids. Hence, the choice for fishes rich in these n-3 fatty acids is not limited.

Among DHA, EPA, and DPA in 88 fish species, DHA was found to be the highest. Further, DPA was not detected in six different fish species and does not seem to depend on the lipid content. For fish species with more than 1,000 mg of the sum of DPA, DHA, and EPA per $100 \mathrm{~g}$, the content of these $\mathrm{n}-3$ fatty acids is in the order of DHA > EPA > DPA, except for laced moray in which the level of DPA is higher than EPA. However, such order is not applicable for fish species with low n-3 fatty acids. 


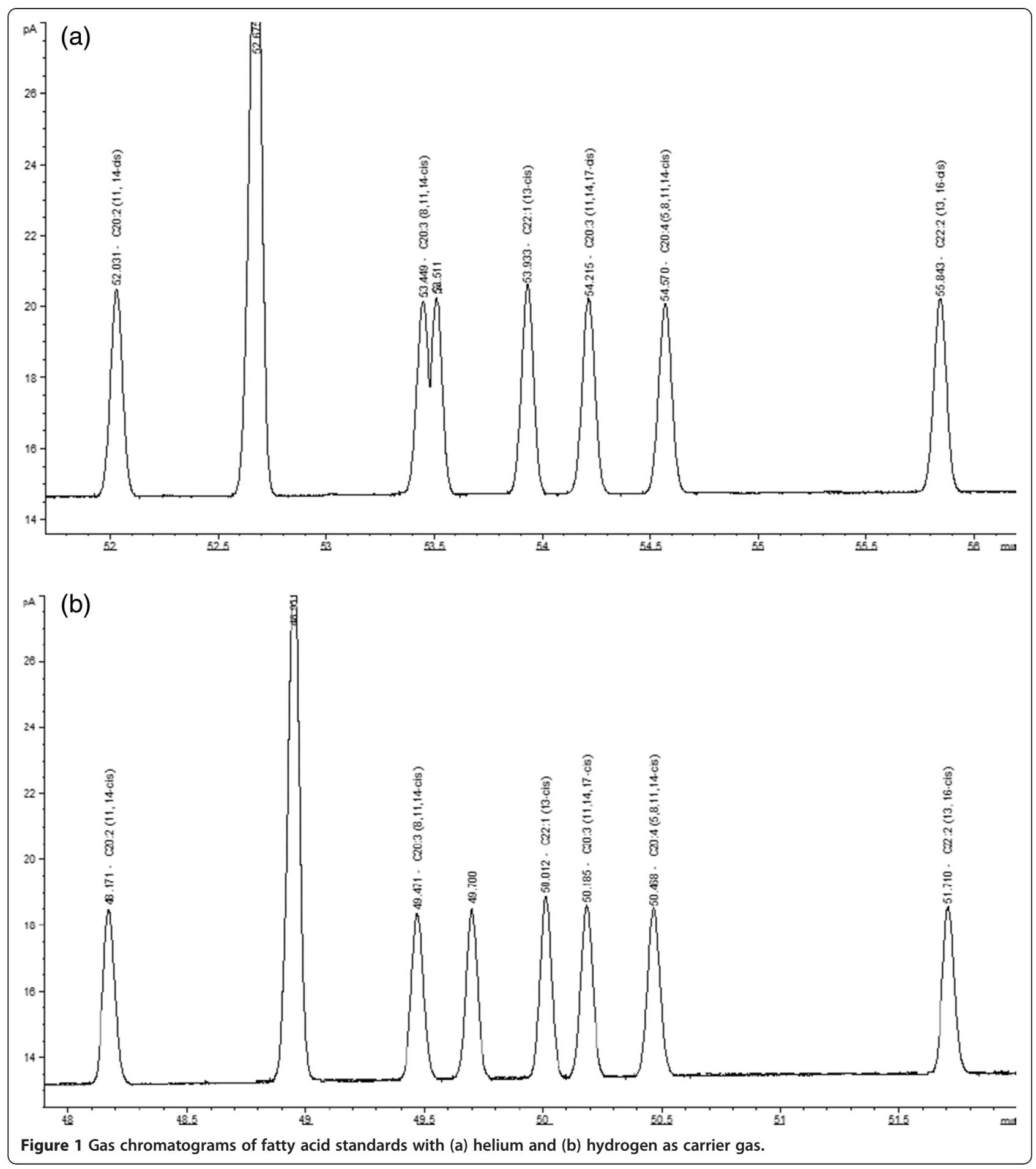

\section{Regional variations}

For samples of fish that shipped from a specific country, it is not necessary true that the fish was caught or produced in that country. It was also noted that in the same Seriola lalandi species, significantly different fatty acid levels were found in samples coming from different regions. Although S. lalandi from region B (in South Pacific Ocean) was just about $10 \%$ shorter than that of region A (in North Pacific Ocean), the n-3 fatty acids content was three times more than that of region A. Figure 2 showed the ratios of n-3 fatty acid and $\mathrm{MeHg}$ of S. lalandi from regions A and B. Furthermore, the major fatty acids from regions A and B were found to be SFA and MUFA, respectively, i.e., significantly different from each other. The fatty acid profiles of 
Table 1 Overview of test results of 88 fish samples collected in this study

\begin{tabular}{|c|c|c|c|c|c|c|c|c|}
\hline Item & Fish species & Common name & $\begin{array}{l}\text { Number of } \\
\text { samples }\end{array}$ & tHg & $\mathrm{MeHg}$ & EPA & DHA & $\mathrm{EPA}+\mathrm{DHA}$ \\
\hline 1 & Acanthopagrus latus & Yellowfin seabream & 4 & 0.041 & 0.034 & 1.28 & 3.34 & 4.62 \\
\hline 2 & Acanthopagrus schlegeli & Black porgy, blackhead seabream & 1 & 0.136 & 0.116 & 0.21 & 0.74 & 0.94 \\
\hline 3 & Anguilla japonica & Japanese eel & 5 & 0.071 & 0.060 & 2.99 & 7.51 & 10.5 \\
\hline 4 & Ariomma indica & Indian ariomma, Indian driftfish & 3 & 0.010 & 0.005 & 0.32 & 1.77 & 2.09 \\
\hline 5 & Aristichthys nobilis & Bighead carp & 3 & 0.036 & 0.029 & 0.33 & 0.52 & 0.85 \\
\hline 6 & Beryx splendens ${ }^{a}$ & Splendid alfonsino & 3 & 1.053 & 0.827 & 0.94 & 2.90 & 3.84 \\
\hline 7 & Branchiostegus albus & White horsehead & 4 & 0.073 & 0.059 & 0.87 & 3.04 & 3.91 \\
\hline 8 & Cephalopholis urodeta & Darkfin hind & 3 & 0.094 & 0.087 & 0.13 & 1.03 & 1.16 \\
\hline 9 & Channa maculata & Snakehead, blotched snakehead & 3 & 0.048 & 0.037 & 0.59 & 2.78 & 3.37 \\
\hline 10 & Choerodon schoenleinii & Green wrasse, blackspot tuskfish & 4 & 0.095 & 0.076 & 0.33 & 0.64 & 0.96 \\
\hline 11 & Cirrhinus molitorella & Mud carp & 3 & 0.039 & 0.030 & 0.61 & 1.20 & 1.81 \\
\hline 12 & Clarias fuscus & Catfish, Hong Kong catfish & 3 & 0.007 & 0.005 & 0.54 & 1.62 & 2.16 \\
\hline 13 & Cololabis saira ${ }^{a}$ & Pacific saury & 3 & 0.056 & 0.042 & 0.16 & 0.36 & 0.52 \\
\hline 14 & Cromileptes altivelis & Humpback grouper & 3 & 0.101 & 0.078 & 0.08 & 0.64 & 0.73 \\
\hline 15 & Ctenopharyngodon idellus & Grass carp & 3 & 0.008 & 0.003 & 0.08 & 0.49 & 0.57 \\
\hline 16 & Cynoglossus arel & Largescale tonguesole, tonguefish & 3 & 0.075 & 0.057 & 0.13 & 0.39 & 0.52 \\
\hline 17 & Cynoglossus bilineatus & Fourlined tonguesole & 3 & 0.039 & 0.028 & 0.13 & 0.55 & 0.68 \\
\hline 18 & Dentex tumifrons & Golden tail, yellowback seabream & 4 & 0.281 & 0.253 & 0.90 & 4.21 & 5.11 \\
\hline 19 & Eleutheronema tetradactylum & Fourfinger threadfin, blind tasselfish & 3 & 0.065 & 0.048 & 3.59 & 4.83 & 8.42 \\
\hline 20 & Epinephelus areolatus & Areolate grouper, green-spotted rock cod & 3 & 0.066 & 0.047 & 1.52 & 5.22 & 6.74 \\
\hline 21 & Epinephelus awoara & Yellow grouper, banded grouper & 3 & 0.118 & 0.087 & 0.35 & 1.16 & 1.51 \\
\hline 22 & Epinephelus bleekeri & Duskytail grouper & 3 & 0.080 & 0.067 & 0.63 & 2.34 & 2.97 \\
\hline 23 & Epinephelus coioides & $\begin{array}{l}\text { Green grouper, orange-spotted grouper, } \\
\text { estuary grouper }\end{array}$ & 3 & 0.057 & 0.047 & 0.34 & 1.33 & 1.67 \\
\hline 24 & $\begin{array}{l}\text { Epinephelus } \\
\text { fasciatomaculosus }\end{array}$ & Rock grouper, banded reef-cod & 3 & 0.086 & 0.063 & 0.66 & 1.20 & 1.86 \\
\hline 25 & Epinephelus hexagonatus & Starspotted grouper & 2 & 0.065 & 0.056 & 0.05 & 0.59 & 0.64 \\
\hline 26 & Epinephelus lanceolatus & Giant grouper & 4 & 0.051 & 0.037 & 2.61 & 4.58 & 7.19 \\
\hline 27 & Epinephelus merra & Honeycomb grouper & 1 & 0.033 & 0.030 & 0.07 & 0.53 & 0.61 \\
\hline 28 & Epinephelus quoyanus & Longfin grouper & 1 & 0.068 & 0.060 & 0.64 & 1.89 & 2.53 \\
\hline 29 & Epinephelus trimaculatus & Threespot grouper & 1 & 0.076 & 0.055 & 0.17 & 0.76 & 0.92 \\
\hline 30 & Gymnothorax favagineus & Laced moray & 1 & 0.166 & 0.123 & 2.29 & 7.13 & 9.42 \\
\hline 31 & Gymnothorax reevesii & Reeve's moray & 3 & 0.067 & 0.055 & 1.05 & 4.05 & 5.10 \\
\hline 32 & Hapalogenys nitens & Skewband grunt, grunt & 3 & 0.118 & 0.078 & 3.64 & 11.90 & 15.5 \\
\hline 33 & Harpadon nehereus & Bombay duck & 3 & 0.017 & 0.013 & 0.14 & 0.43 & 0.57 \\
\hline 34 & Katsuwonus pelamis & Skipjack tuna & 3 & 0.143 & 0.128 & 0.12 & 0.97 & 1.09 \\
\hline 35 & Larimichthys croceus & $\begin{array}{l}\text { Yellow croaker, croceine croaker, large } \\
\text { yellow croaker }\end{array}$ & 3 & 0.044 & 0.036 & 3.41 & 9.52 & 12.9 \\
\hline 36 & Lateolabrax japonicus & $\begin{array}{l}\text { Japanese seaperch, common sea bass, } \\
\text { Japanese seabass }\end{array}$ & 5 & 0.038 & 0.028 & 0.73 & 1.59 & 2.32 \\
\hline 37 & Lates calcarifer & Barramundi & 6 & 0.091 & 0.077 & 0.24 & 0.71 & 0.95 \\
\hline 38 & Lethrinus obsoletus & Orange-striped emperor & 2 & 0.050 & 0.037 & 0.11 & 0.44 & 0.55 \\
\hline 39 & Lutjanus argentimaculatus & Mangrove red snapper & 5 & 0.060 & 0.046 & 0.49 & 1.16 & 1.65 \\
\hline 40 & Lutjanus malabaricus & Red snapper, Malabar blood snapper & 3 & 0.106 & 0.078 & 0.29 & 1.02 & 1.31 \\
\hline 41 & Lutjanus russelli & Russell's snapper, fingermark bream & 3 & 0.112 & 0.087 & 0.12 & 0.94 & 1.07 \\
\hline
\end{tabular}


Table 1 Overview of test results of 88 fish samples collected in this study (Continued)

\begin{tabular}{|c|c|c|c|c|c|c|c|c|}
\hline 42 & Lutjanus stellatus & Star snapper & 3 & 0.161 & 0.105 & 0.53 & 1.53 & 2.06 \\
\hline 43 & Megalobrama terminalis & Black amur bream & 1 & 0.007 & 0.006 & 0.10 & 0.21 & 0.31 \\
\hline 44 & Micropterus salmoides & Largemouth bass, largemouth black bass & 3 & 0.069 & 0.050 & 1.12 & 4.25 & 5.37 \\
\hline 45 & Mugil cephalus & Grey mullet, flathead grey mullet & 3 & 0.014 & 0.009 & 1.00 & 1.35 & 2.35 \\
\hline 46 & Mulloidichthys flavolineatus & Yellowstripe goatfish & 1 & 0.042 & 0.030 & 0.22 & 0.81 & 1.03 \\
\hline 47 & Nemipterus japonicus & Japanese golden thread, Japanese threadfin bream & 4 & 0.036 & 0.031 & 0.89 & 1.73 & 2.62 \\
\hline 48 & Nemipterus virgatus & Golden threadfin bream, golden thread & 3 & 0.054 & 0.041 & 1.16 & 3.63 & 4.79 \\
\hline 49 & $\begin{array}{l}\text { Oreochromis niloticus } \\
\text { niloticus }\end{array}$ & Tilapia, Nile tilapia & 4 & 0.017 & 0.013 & 0.06 & 0.65 & 0.70 \\
\hline 50 & Pagrus major & Red pargo, Japanese seabream, Red seabream & 3 & 0.051 & 0.039 & 1.70 & 6.41 & 8.11 \\
\hline 51 & Pampus argenteus & Silver pomfret, butterfish, pomfret & 5 & 0.017 & 0.011 & 2.42 & 7.70 & 10.1 \\
\hline 52 & Pampus nozawae & Swallow tail pomfret & 3 & 0.024 & 0.015 & 0.97 & 4.02 & 4.99 \\
\hline 53 & Paralichthys olivaceus ${ }^{a}$ & False halibut, bastard halibut & 3 & 0.048 & 0.035 & 4.26 & 7.90 & 12.2 \\
\hline 54 & Parupeneus barberinus & Dash-and-dot goatfish & 1 & 0.15 & 0.136 & 0.14 & 0.43 & 0.57 \\
\hline 55 & Parupeneus indicus & Indian goatfish & 2 & 0.188 & 0.166 & 0.87 & 1.19 & 2.06 \\
\hline 56 & Pennahia argentata & White croaker, white chinese croaker, silver croaker & 5 & 0.079 & 0.062 & 0.19 & 1.86 & 2.05 \\
\hline 57 & Platycephalus indicus & Flathead, bartail flathead & 4 & 0.108 & 0.081 & 0.66 & 1.62 & 2.28 \\
\hline 58 & Platycephalus spp & Flathead & 1 & 0.051 & 0.041 & 0.59 & 2.05 & 2.64 \\
\hline 59 & Plectorhinchus cinctus & Cresent sweetlips, grunt & 3 & 0.064 & 0.050 & 0.10 & 1.01 & 1.11 \\
\hline 60 & Plectropomus areolatus & Squaretail coralgrouper & 2 & 0.091 & 0.068 & 0.13 & 1.04 & 1.17 \\
\hline 61 & Plectropomus leopardus & Leopard coralgrouper & 4 & 0.052 & 0.042 & 0.14 & 1.46 & 1.60 \\
\hline 62 & Pomadasys kaakan & Javelin grunter & 4 & 0.090 & 0.078 & 0.20 & 1.09 & 1.29 \\
\hline 63 & Priacanthus tayenus & Purple-spotted bigeye, big-eye perch & 4 & 0.044 & 0.033 & 0.50 & 2.00 & 2.50 \\
\hline 64 & Priacanthus macracanthus & Red bigeye, bulls-eye perch & 2 & 0.019 & 0.012 & 0.28 & 1.82 & 2.10 \\
\hline 65 & Psenopsis anomala & Butter fish, Pacific rudderfish & 4 & 0.013 & 0.010 & 0.54 & 1.45 & 1.99 \\
\hline 66 & Pseudocaranx dentex $x^{a}$ & White trevally & 3 & 0.101 & 0.084 & 5.13 & 8.70 & 13.8 \\
\hline 67 & Rachycentron canadum & Black bonito, cobia & 1 & 0.101 & 0.100 & 0.15 & 0.43 & 0.57 \\
\hline 68 & Salmo Salar & Atlantic salmon & 3 & 0.034 & 0.025 & 8.40 & 12.20 & 20.6 \\
\hline 69 & Sarda orientalis ${ }^{\mathrm{a}}$ & Striped bonito & 3 & 0.101 & 0.076 & 0.57 & 1.62 & 2.19 \\
\hline 70 & Sardinops sagax ${ }^{a}$ & South American pilchard & 3 & 0.031 & 0.026 & 0.54 & 2.10 & 2.64 \\
\hline 71 & Saurida elongata & Slender lizardfish & 2 & 0.020 & 0.016 & 0.63 & 2.71 & 3.34 \\
\hline 72 & Saurida tumbil & Greater lizardfish & 1 & 0.024 & 0.018 & 0.62 & 2.79 & 3.41 \\
\hline 73 & Scatophagus argus & Spotted scat, butter fish, spade fish & 3 & 0.034 & 0.028 & 0.82 & 3.00 & 3.82 \\
\hline 74 & Scomber japonicus ${ }^{\mathrm{a}}$ & Chub mackerel & 3 & 0.213 & 0.152 & 0.19 & 1.02 & 1.21 \\
\hline 75 & Scomberomorus commerson & $\begin{array}{l}\text { Narrow-barred Spanish mackerel, albacore, } \\
\text { banded tuna }\end{array}$ & 1 & 0.083 & 0.059 & 0.45 & 2.21 & 2.66 \\
\hline 76 & Scomberomorus guttatus & Indo-pacific king mackerel & 5 & 0.087 & 0.069 & 0.38 & 2.21 & 2.59 \\
\hline 77 & Sebastiscus marmoratus & Rockfish & 3 & 0.033 & 0.025 & 0.82 & 1.68 & 2.50 \\
\hline 78 & Seriola dumerili & Purple amberjack, greater amberjack & 3 & 0.113 & 0.089 & 4.31 & 8.33 & 12.6 \\
\hline $79 \mathrm{~A}$ & Seriola lalandia (Region A) & Yellowtail kingfish, Yellowtail amberjack & 3 & 0.219 & 0.192 & 0.65 & 2.47 & 3.12 \\
\hline $79 B$ & Seriola lalandi (Region B) & Yellowtail kingfish, Yellowtail amberjack & 3 & 0.031 & 0.023 & 6.08 & 6.70 & 12.8 \\
\hline 80 & Siganus canaliculatus & $\begin{array}{l}\text { Rabbitfish, pearl-spotted spinefoot, } \\
\text { white-spotted spinefoot }\end{array}$ & 3 & 0.014 & 0.009 & 0.70 & 5.33 & 6.03 \\
\hline 81 & Sillago japonica & Japanese sillago & 3 & 0.133 & 0.117 & 0.41 & 1.13 & 1.54 \\
\hline 82 & Siniperca chuatsi & Freshwater grouper, Mandarin fish & 3 & 0.091 & 0.077 & 0.62 & 1.28 & 1.90 \\
\hline 83 & Sphyraena flavicauda ${ }^{a}$ & Yellowtail barracuda, barracudas & 3 & 0.295 & 0.216 & 0.40 & 0.91 & 1.30 \\
\hline
\end{tabular}


Table 1 Overview of test results of 88 fish samples collected in this study (Continued)

\begin{tabular}{|c|c|c|c|c|c|c|c|c|}
\hline 84 & Trachinotus blochii & Snubnose pompano & 3 & 0.056 & 0.048 & 0.20 & 1.37 & 1.57 \\
\hline 85 & Trachurus japonicus $^{\mathrm{a}}$ & Japanese jack mackerel, Atlantic horse mackerel & 3 & 0.064 & 0.042 & 0.24 & 0.82 & 1.06 \\
\hline 86 & Trichiurus lepturus & Largehead hairtail, hairtail & 5 & 0.091 & 0.069 & 0.65 & 2.83 & 3.48 \\
\hline 87 & Trichiurus nanhaiensis & Largehead hairtail, South China Sea hairtail & 1 & 0.056 & 0.042 & 0.16 & 1.03 & 1.19 \\
\hline 88 & Variola albimarginata & White-edged Iyretail & 3 & 0.102 & 0.073 & 0.06 & 0.73 & 0.79 \\
\hline
\end{tabular}

Note: Concentration of $\mathrm{tHg}$ and $\mathrm{MeHg}$ was in $\mathrm{ug} / \mathrm{g}$ while $\mathrm{n}-3$ fatty acids were in $\mathrm{mg} / \mathrm{g}$ respectively.

${ }^{\text {a } D e n o t e ~ i m p o r t e d ~ f i s h . ~}$

these two regions were significantly different; hence, it is plausible that variation in living environments is an important factor in determining the fatty acid profile and content of $\mathrm{MeHg}$ in fish.

\section{Relationship between $\mathrm{MeHg}$ and $\mathrm{n}-3$ fatty acids}

Figure 3 plotted the $\mathrm{n}-3$ fatty acids and $\mathrm{MeHg}$ contents of 88 fish species. Besides alfonsino that had high $\mathrm{MeHg}$ and low n-3 fatty acids, other tested fish species were found to have relatively low $\mathrm{MeHg}$ content. This finding suggested that pregnant women, women planning pregnancy, and young children when selecting fish species in their diet should avoid eating predatory fish, alfonsino. In general, the plot is comparable to that reported by Mahaffey et al. (2008) and FAO/WHO study. It should be noted that only those fish species where the whole fish was available in the market were sampled.
Some imported fish that contained high levels of mercury were not available as whole fish and were therefore not included in the sampling and analyses in this study. Predator fish that were not sampled included swordfish, shark, marlin, tilefish, orange roughy, and other species of tuna (bluefin, bigeye, albacore, and yellowfin). Generally, predator fish were located in the region of low n-3 fatty acid and high level of $\mathrm{MeHg}$ in the chart plotting the levels of MeHg and n-3 fatty acids (EPA and DHA). However, both Zhang et al. [10] and FAO/WHO studies reported that Pacific bluefin tuna got high n-3 fatty acids and $\mathrm{MeHg}$. In this study, the skipjack tuna sampled was found to have low n-3 fatty acids and $\mathrm{MeHg}$.

Regarding the relative contents of $\mathrm{MeHg}$ of $\mathrm{tHg}$ in different fish species, i.e., the ratios of $\mathrm{MeHg}$ to $\mathrm{tHg}$ were in the range of 0.46 to 0.99 and in good agreement with the literature [16-19]. Therefore, the relationship between $\mathrm{tHg}$ and $\mathrm{n}-3$ fatty acids is similar to that of $\mathrm{MeHg}$ and $\mathrm{n}-3$ fatty acids.

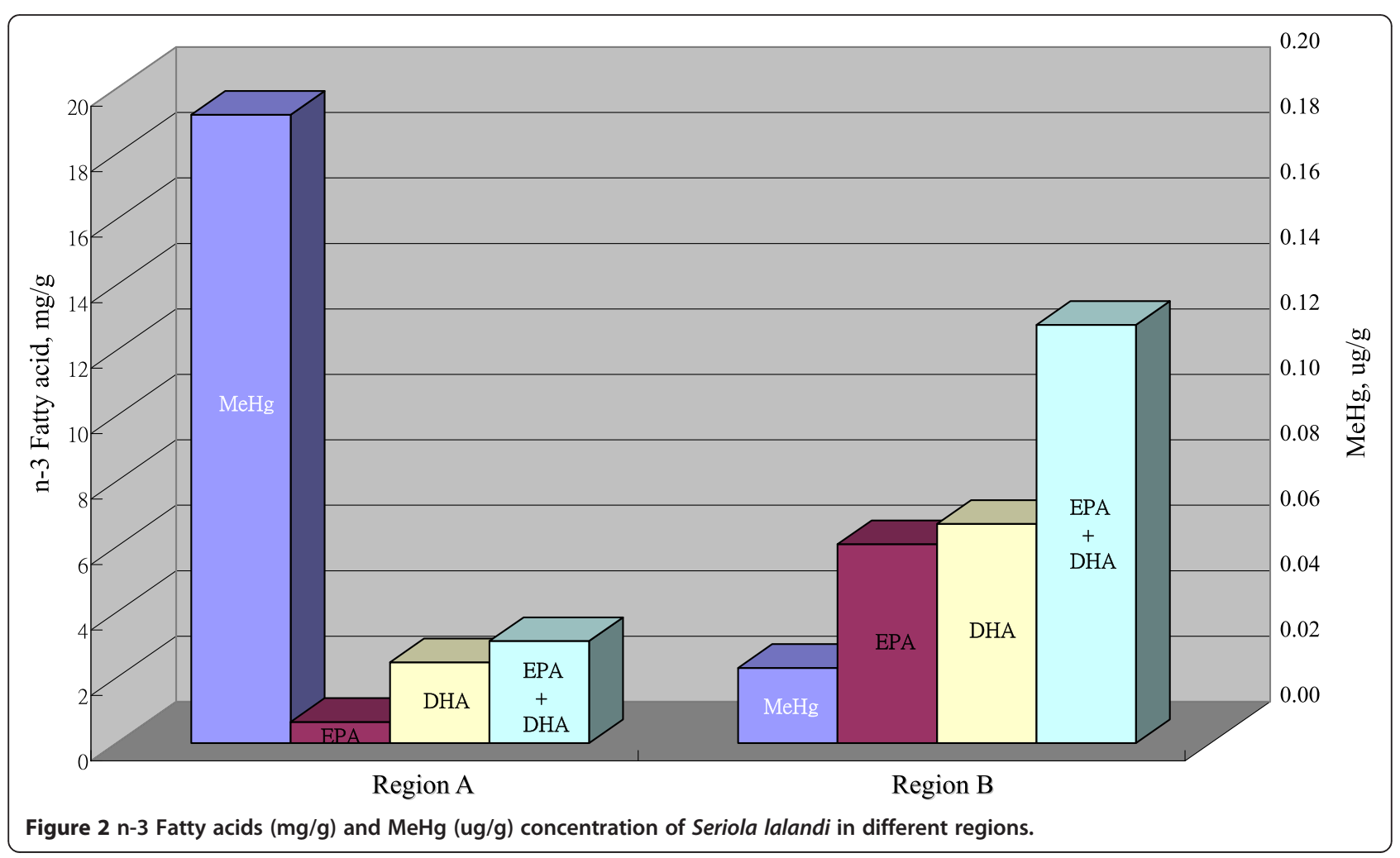




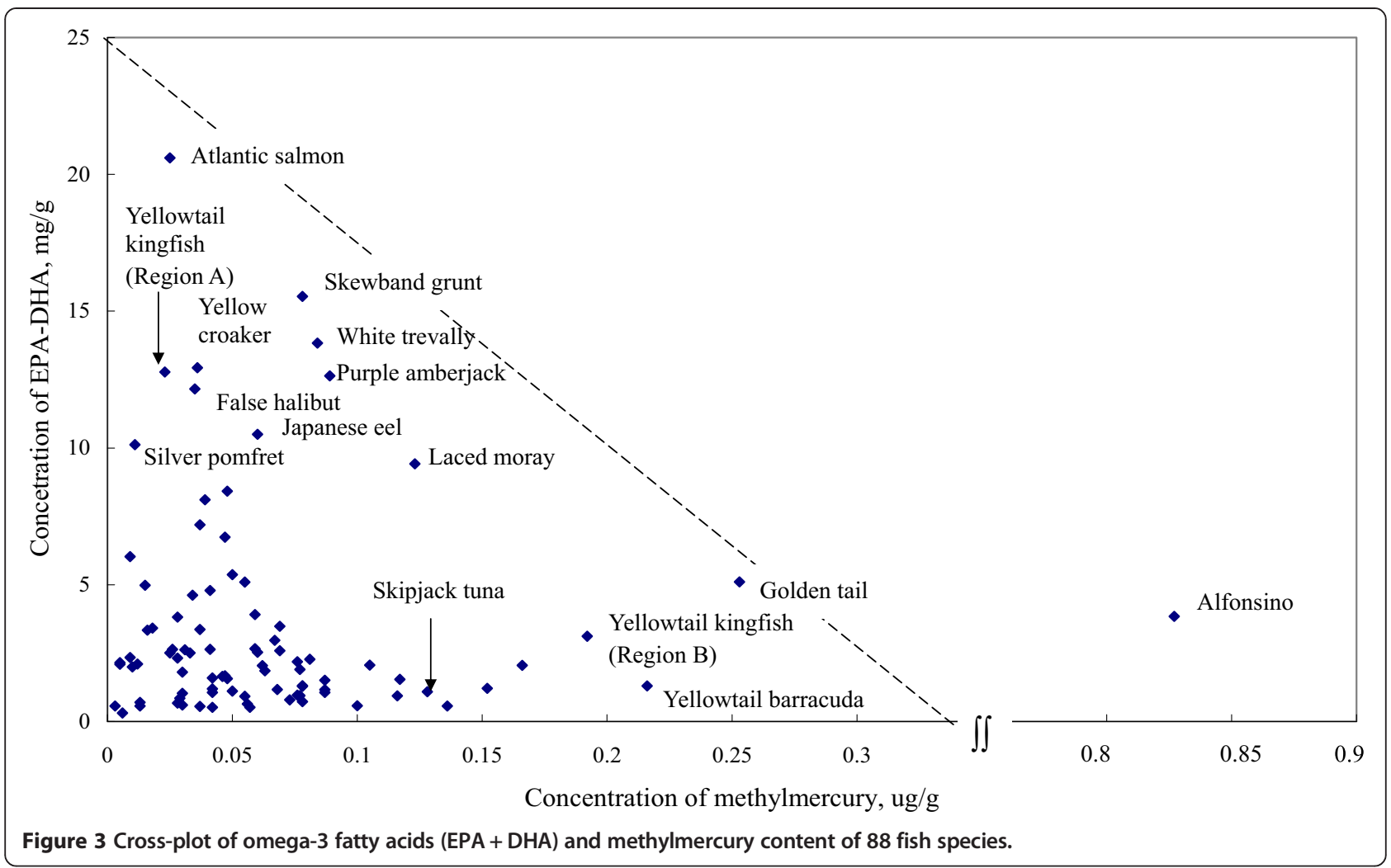

For each of the 88 fish species, the contents of $\mathrm{MeHg}$ and n-3 fatty acids (EPA plus DHA) were classified according to its levels in Table 2. When compared to the FAO/WHO study, the n-3 fatty acids of fish species are, in general, lower than that found in other countries. One of the possible reasons is that quite a number of different fish species available in Hong Kong is farmed, which included grouper, eel, snapper, etc. Therefore, the feed used would affect the level of n-3 fatty acids. For those wild fish, such as skipjack tuna and alfonsino, the living region is an important factor in determining the contents of $\mathrm{MeHg}$ and $\mathrm{n}-3$ fatty acids. With reference to the present finding, most of the fish species, greater than $80 \%$ have mean $\mathrm{MeHg}$ levels of lower than $0.1 \mathrm{ug} / \mathrm{g}$. Out of the 88 fish species, 25 different fish species could provide $\mathrm{n}-3$ fatty acids greater than $3 \mathrm{mg} / \mathrm{g}$. Further, $\mathrm{n}-3$ fatty acids of 11 and 2 of these 25 fish species were found to greater than 8 and $15 \mathrm{mg} / \mathrm{g}$ on flesh weight, respectively.

In summary, the observed difference between this study and other similar studies might due to the fact that other datasets usually pooled data from different databases. Furthermore, the living environment is an important determinant of both $\mathrm{n}-3$ fatty acids and $\mathrm{MeHg}$ levels. As

Table 2 Classification of the content of EPA plus DHA by methylmercury content in 88 fish species

\begin{tabular}{|c|c|c|c|c|}
\hline Methylmercury & MEPA + DHA & & & \\
\hline & $x \leq 3 \mathrm{mg} / \mathrm{g}$ & $3<x \leq 8 \mathrm{mg} / \mathrm{g}$ & $8<x \leq 15 \mathrm{mg} / \mathrm{g}$ & $x>15 \mathrm{mg} / \mathrm{g}$ \\
\hline$x \leq 0.1 \mu \mathrm{g} / \mathrm{g}$ & $\begin{array}{l}\text { Other fish species included } \\
\text { in the study }\end{array}$ & $\begin{array}{l}\text { Yellowfin seabream, white } \\
\text { horsehead, snakehead, areolate } \\
\text { grouper, giant grouper, Reeve's } \\
\text { moray, largemouth bass, golden } \\
\text { threadfin bream, swallow tail pomfret, } \\
\text { slender lizardfish, greater lizardfish, } \\
\text { spotted scat, rabbitfish, largehead } \\
\text { hairtail }\end{array}$ & $\begin{array}{l}\text { Japanese eel, fourfinger threadfin, } \\
\text { yellow croaker, red pargo, silver } \\
\text { pomfret, false halibut, white trevally, } \\
\text { purple amberjack, yellowtail kingfish }\end{array}$ & $\begin{array}{l}\text { Atlantic salmon, } \\
\text { skewband grunt }\end{array}$ \\
\hline $0.1<x \leq 0.5 \mu \mathrm{g} / \mathrm{g}$ & $\begin{array}{l}\text { Black porgy, skipjack tuna, star } \\
\text { snapper, dash-and-dot goatfish, } \\
\text { Indian goatfish, chub mackerel, } \\
\text { Japanese sillago, yellowtail } \\
\text { barracuda }\end{array}$ & Golden tail, yellowtail kingfish & Laced moray & \\
\hline$x>0.5 \mu \mathrm{g} / \mathrm{g}$ & & Alfonsino & & \\
\hline
\end{tabular}


suggested by $\mathrm{FAO} / \mathrm{WHO}$, local data with both the levels of MeHg and n-3 fatty acids should be obtained from different fish species to obtain a better picture.

\section{Conclusions}

This study provides both the n-3 fatty acid (EPA plus DHA) and MeHg levels of the most common fish species marketed in Hong Kong. Of the fish examined, 25 fish species containing $\mathrm{MeHg}$ of less than $0.1 \mu \mathrm{g} / \mathrm{g}$ and $\mathrm{n}-3$ fatty acids greater than $3 \mathrm{mg} / \mathrm{g}$ were considered suitable as source of n-3 fatty acids. Eleven of these fish species were also found to contain high levels of n-3 fatty acids in the range of greater than $8 \mathrm{mg} / \mathrm{g}$ on flesh weight. The data of this study provide useful information to improve the existing databases on $\mathrm{MeHg}$ in fish in Hong Kong and nearby region.

\section{Additional file}

Additional file 1: Table S1. Overview of other $\mathrm{n}-3$ fatty acids (mg/g)

results of fish samples collected in this study.

\section{Competing interests}

The authors declare that they have no competing interests.

\section{Authors' contributions}

SKT has performed all the experimental and analytical work. SWCC guided the research and drafted the manuscript. YX and YYH provided comments and modified the manuscript. All authors read and approved the final manuscript.

\section{Acknowledgements}

Special thanks are made to Ms. Valerie C. M. HO and Dr. Albert W.Y. LEUNG of the Agriculture, Fisheries and Conservation Department who conducted the fish species identification.

\section{Author details}

${ }^{1}$ Food Research Laboratory, Food and Environmental Hygiene Department, 4/F Public Health Laboratory Centre, 382 Nam Cheong Street, Shek Kip Mei, Hong Kong, China. ${ }^{2}$ Risk Assessment Section, Food and Environmental Hygiene Department, 43/F Queensway Government Offices, Queensway, Hong Kong, China. ${ }^{3}$ Risk Assessment and Communication Division, Food and Environmental Hygiene Department, 45/F Queensway Government Offices, Queensway, Hong Kong, China.

Received: 2 January 2014 Accepted: 19 January 2015

Published online: 15 February 2015

\section{References}

1. Médale F, Lefèvre F, Corraze G (2003) Qualité nutritionnelle et diététique des poissons, constituants de la chair et facteurs de variations. Cahiers de Nutrition et de Diététique 38(1):37-44

2. WHO. 2003. Diet, nutrition and the prevention of chronic diseases, WHO Technical Series Report 916 (Geneva). Accessed January 2015 at: http://whqlibdoc.who.int/trs/who_trs_916.pdf

3. WHO. 2000. Safety evaluation of certain food additives and contaminants WHO Food Additive Series No. 44, Methylmercury. Geneva: WHO. Accessed January 2015 at: http://www.inchem.org/documents/jecfa/jecmono/ v44jec13.htm

4. WHO. 2004. Safety evaluation of certain food additives and contaminants WHO Food Additive Series No. 52. Methylmercury (Addendum) 2004. Accessed January 2015 at: http://www.inchem.org/documents/jecfa/ jecmono/v52je23.htm
5. U.S. Food and Drug Administration. 2004. What you need to know about mercury in fish and shellfish. (Brochure) Accessed January 2015 at: http://www.fda.gov/food/resourcesforyou/consumers/ucm110591.htm

6. Food Standards Australia New Zealand (FSANZ). 2011. Mercury in fish. Accessed January 2015 at: http://www.foodstandards.gov.au/consumer/ chemicals/mercury/pages/default.aspx

7. Mahaffey KR (2004) Fish and shellfish as dietary sources of methylmercury and the o-3 fatty acids, eicosahexaenoic acid and docosahexaenoic acid: risks and benefits. Environmental Research 95:414-28

8. Agence Française de Sécurité Sanitaire des Aliments (AFSSA). 2006. CALIPSO Fish and seafood consumption study and biomarker of exposure to trace elements, pollutants and omega 3. Accessed January 2015 at: https://www. anses.fr/sites/default/files/documents/PASER-Ra-CalipsoEN.pdf

9. Mozaffarian D, Rimm EB (2006) Fish intake contaminants, and human health evaluating the risks and the benefits. Journal of the American Medical Association 296:1885-99

10. Zhang Y, Nakai S, Masunaga S (2009) Simulated impact of a change in fish consumption on intake of $\mathrm{n}-3$ polyunsaturated fatty acids. Journal of Food Composition and Analysis 22:657-62

11. U.S. Food and Drug Administration. 2009. Draft report of quantitative risk and benefit assessment of consumption of commercial fish, focusing on fetal neurodevelopmental effects (measured by verbal development in children) and on coronary heart disease and stroke in the general population. Accessed January 2015 at: http://www.fda.gov/Food/FoodbornelllnessContamin ants/Metals/ucm088794.htm

12. FAO/WHO. 2010. Report of the Joint FAO/WHO Expert Consultation on the risks and benefits of fish consumption. Accessed January 2015 at: http://www.fao.org/docrep/014/ba0136e/ba0136e00.pdf

13. U.S. Food and Drug Administration. Mercury levels in commercial fish and shellfish (1990-2010). Accessed January 2015 at: http://www.fda.gov/Food/ FoodbornelllnessContaminants/Metals/ucm115644.htm

14. Tang SP, Kwong KP, Chung WC, Ho YY, Xiao Y (2009) Dietary exposure to total mercury and methylmercury from fish intake in Hong Kong secondary school students Food Additives and Contaminants. Part B 2:8-14

15. Chung SWC, Kwong KP, Tang ASP, Xiao Y (2008) Mercury and methylmercury levels in main traded fish species in Hong Kong. Food Additives and Contaminants: Part B 1(2):106-13

16. Agah H, Leermakers M, Elskens M, Mohamad Reza Fatemi S, Baeyens W (2007) Total mercury and methyl mercury concentrations in fish from the Persian Gulf and the Caspian Sea. Water Air and Soil Pollution 181:95-106

17. Al Majed N, Preston M (2000) An assessment of the total and methylmercury content of zooplankton and fish tissue in the Kuwait terristorial waters. Marine Pollution Bulletin 40:297-307

18. Landaluze JS, Diego A, Raposo JC, Madariaga JM (2004) Methylmercury determination in sediments and fish tissues from the Nerbioi-lbaizabal estuary (Basque Country, Spain). Analytica Chimica Acta 508:107-17

19. Houserova P, Kuban V, Kracmar S, Sitko J (2007) Total mercury and mercury species in birds and fish in an aquatic ecosystem in the Czech Republic. Environmental Pollution 145(1):185-94

\section{Submit your manuscript to a SpringerOpen ${ }^{\odot}$ journal and benefit from:}

- Convenient online submission

- Rigorous peer review

- Immediate publication on acceptance

- Open access: articles freely available online

- High visibility within the field

- Retaining the copyright to your article

Submit your next manuscript at $\boldsymbol{\wedge}$ springeropen.com 